Vol. 5, No. 1, 2019

Bohdan Cherkes, Violetta Radomska

\title{
CURRENT STATE OF PRESERVATION \\ AND PROBLEMATICS OF RESTORING POL YCHROME PAINTINGS BY MODEST SOSENKO IN THE STRUCTURE OF SACRED ARCHITECTURE
}

\author{
Lviv Polytechnic National University \\ 12, S. Bandery Str., Lviv, 79013, Ukraine \\ tscherkes53@gmail.com,orcid.org/0000-0001-6809-956X \\ w.r.radomska@gmail.com,orcid:0000-0001-6868-868X
}

Received: 25.04.2019 / Revised: 03.07.2019/Accepted: 10.07.2019

(C) Cherkes B., Radomska V., 2019

\begin{abstract}
The current tendency of preserving monuments of immovable cultural heritage has gained negative connotations since the conservation treatment activities executed by state and religious communities that become 'owners' of significant sacred objects still lacks the sufficient legislative regulation. The synchronization of multidisciplinary studies of specialists in different areas is extremely important for the comprehensive preservation of an architectural object. A bright example is constituted by the preservation state of murals by Modest Sosenko (1875-1920), a famous modernist of the first quarter of the XXth century, which are painted in the interior space of Ukrainian churches. Deterioration processes, ideological prerogatives, and changes of aesthetic principles have resulted in the total destruction of these unique pieces of decorative and monumental art. The preservation state and the problematics of restoring sacred polychrome paintings by Modest Sosenko on the terrains of Lviv region have been analyzed as those based on the empirical, scientific, and restoration studies.
\end{abstract}

Key words: polychrome painting, sacred architecture, Modest Sosenko, preservation, restoration, physical and chemical research, restoration probing.

\section{Introduction}

Taking into account the dynamics of destructing the authenticity of architectural monuments, particularly the total 'renewal' of polychrome paintings and the supplementation of temple interiors with objects, the interdisciplinary approach to observation, scientific identification, certification, comprehensive conservation, and restoration of an object becomes more topical. Conclusions of the art expert evaluation, which are based on the archive documents, literary sources or visual observation, do not always render the real state of preserving the authenticity of a definite work. To determine the objective state of preserving original murals within an architectural monument, scientists apply the method of scientific and restoration research of the material structure of polychrome paintings, which enables the possibility of elaborating the efficient scheme of actions for the comprehensive preservation of architecture. 


\section{Analysis of recent studies and publications}

The idea of determining the efficient ways of preservation and the aesthetic approach to conservation and restoration practice within the area of decorative and monumental art within an architectural object is analyzed by Cesare Brandi (Cesare Brandi, 2006, p. 7-66). The information about preservation of church polychrome paintings and iconostases by Modest Sosenko is taken from the publications of the art expert O. Semchyshyn-Huzner (O. Semchyshyn-Huzner, 2014, p. 46-52), the restoration artist V. Radomska (Radomska, 2009, p. 190-195, 2010, p. 171-178). The topic of uncovering and preserving polychrome paintings is highlighted in the articles of I. Z. Dutkevych, O. B. Rishniak, O. Ya. Sadova, P. Bolinskyi, R. S. Herman, A. I. Pochekva, T. O. Kondratiuk and the XIth International Scientific and Practical Conference organized to mark the $80^{\text {th }}$ anniversary of founding the National Scientific and Research Restoration Center in Ukraine (NSRRC), 2019, Kyiv (edited by Strelnikova, 2019, p.109-114, 177-182, 246-250, 376-380).

\section{Research objective}

The objective of the article is to highlight the current preservation state of polychrome paintings by Modest Sosenko in the interior space of Archangel Michael Church (Arkhanhel Mykhail Church) in Pidberiztsi village, St. Nicholas Church (Sviatyi Mykolai Church) in Zolochiv, and Church of Resurrection of Christ (Voskresinnia Hospodnie Church) in Polyany village, Lviv region, as based on the scientific and restoration analytics. The research aims at determining the authenticity of murals, the stages of restoration interventions, the preservation state and the non-destructive ways of conservation and restoration work. The analytics outlined in the article is based on multiple expeditions to architectural objects, physical and chemical laboratory analysis, and practical application of restoration procedures (2015), which facilitate the professional preservation of authenticity of polychrome paintings by Modest Sosenko in the interiors of Archangel Michael Church in Pidberiztsi and Church of Resurrection of Christ in Polyany.

\section{Results and Discussion}

The key component of adapting monuments of art and architecture to the requirements of any epoch is time, which performs the function of mediation between the final creative process and the moment when this creative act, i.e. monument of art and architecture, arises in the consciousness of an observer belonging to a certain epoch. The distance between the moments in time with respect to evaluating the eternal and the historical aspects brings about the conflict that can significantly affect the preservation of an object. As a result of transformations, different alterations in terms of shape and content, destructions, reconstructions, and reformatting, a certain art object becomes topical for the society and, simultaneously, remains a part of cultural and historical past (Cesare Brandi, 2006, p. 35-39). A study of the main principles of stratigraphic and technological structure of wall paintings as an example of decorative and monumental art constitutes the significant stage of preserving the monument in general. The search for new technological materials and the change of aesthetic, social, and cultural prerogatives significantly changes the methods and the technical and technological principles of decorating architectural buildings. Currently, the study of authenticity of monumental art dating back to the first half of the $\mathrm{XX}^{\text {th }}$ century, namely the determination of authorship, the confirmation of previous attributions or the attribution of new objects, is at the initial stage of development as compared to the study of panel painting. Art expert evaluations based exclusively on archive and historic data do not always correspond to the real state of preservation. The situation becomes more complicated when the preserved architectural ensembles are dated or identified taking into account only the indirect evidence, such as age determination of an architectural environment (data taken from the history of a temple, graffiti with dates on the walls, 
paleography, inscriptions, etc.). Another type of evidence, which is iconographic and stylistic analysis, cannot always serve as the basis for dating or identification of an author because paintings can be changed and renewed multiple times. For the sake of establishing the chronological connection between interior decorations and architectonics of a construction, we should pay attention to the decisive role of the scientific and technological study of the physical structure of layers that constitute a certain type of architectural monument. The topic that has not been highlighted so far in the national scientific historiography deals with the creation of an analytical database of individual methods, principles, technical and technological specificity of the Ukrainian monumental artists who created their works in the first quarter of the XXth century. One of the talented representatives of this group of innovators is Modest Sosenko (1875-1920), who in the early XXth century introduced a new type of organizing the interior space of sacred buildings and, thus, created 'Ukrainian' Neo-Byzantine direction combined with the strongly pronounced modernism stylistics of that time. Taking into account the research objectives, we have determined the preservation state of polychrome paintings by Modest Sosenko in the architecture of three churches in Lviv region and outlined the set of recommendations concerning their preservation and restoration. The general scientific and special methods of research have been applied. They served as the basis for developing the comprehensive methodology of studying polychrome paintings in architecture, which apart from the theoretical aspects presupposes drawing scientific and restoration conclusions on the basis of field observations, physical and chemical laboratory examination, research interviews.

The construction of Archangel Michael Church in Pidberiztsi, Pustomyty district, Lviv region (architect V. Nahirnyi) was finished in 1891. Modest Sosenko executed organization of the interior space in 1907-1910 actively collaborating with the firm of I. Levynskyi as a stylist and decorator, icon painter, designer of stainedglass windows and iconostases.

This is a brick crossed-dome temple, which has a two-armed cross with a longer descending part (nave, narthex) and an octagonal drum of a dome at the transept crossing (four main sides are smaller), which is crowned by a lantern with an onion dome. The eastern part of the temple has a rounded apse with a hemispheric top (Fig. 1). The architectural space of the temple is divided in accordance with the basic functions of a temple of the byzantine rite. The temple interior is the expression of harmony and interconnection between the architectural and constructive intention of the architect and the stylistic organization of the sacred space (Fig. 1-3). At the first glance, the preservation state of the authentic polychrome paintings by Modest Sosenko is satisfactory. However, as those of 2019, the material structure of the paint layers is exposed to serious deterioration processes. In 1980s, the group of professional restoration artists under the supervision of $\mathrm{N}$. Prysiazhna performed the reinforcement test of the powdering pigment of authentic polychrome paintings and cleaned the surface contamination that partially distorted the original coloristic patterns (last eastern pilaster of the nave). However, restoration works were stopped due to the lack of funds. During mechanical interventions, the powdering nature of pigment causes its loss and gradual peeling from the wall. Such mechanical damage ruins the elegance and integrity of a colorful compositional image of a painting and causes its elimination with the help of faster and less pricy procedures, as it happened with the repainting of transept niches back in 2008. One of the priorities of the further monument preservation is to discontinue the practice of fragmentary renewals that occur in the structure of polychrome paintings (authentic inscription above the narthex, repeated oil-based coats of panels in the nave). The availability of multiple oil-based coats led to the cease of ventilation of walls and plaster. The condensed moisture in the brick laying and the lime and sand plaster resulted in accumulation and reproduction of microbes, appearance of salt efflorescence, etc., and, consequently, its detachment from the walls and powdering. In July 2008, "Restoration practice" (restoration artist V. Radomska) was organized and its primary objective was: - to uncover the original polychrome paintings by M. Sosenko located in the northern and southern niches of transept from the re-paintings made in 1970s and 2008; - to cease the subsequent unprofessional restoration interventions; - to develop and test in practice the program of the subsequent comprehensive restoration of this unique monument 
of architectural polychrome, created by Modest Sosenko in the first quarter of the XXth century (restoration artists I. Dutkevych and V. Radomska).

The stratigraphic analysis of historical and technological layers, as well as the physical and chemical examination conducted in the laboratory at the Faculty of Conservation and Restoration of Works of Arts at the Academy of Fine Arts in Krakow (ASP, Krakow, Poland) served as the basis for elaborating and implementing the restoration program. The selected techniques were practically tested on different problematic areas of the object. High stabilizing possibilities of the applied techniques were noticed in regards to the powdering nature of polychrome pigment. The restoration program would enable the possibility of reinforcing the surface of the painting and simultaneously making the surface contamination that distorts the coloristic patterns of the murals much thinner.

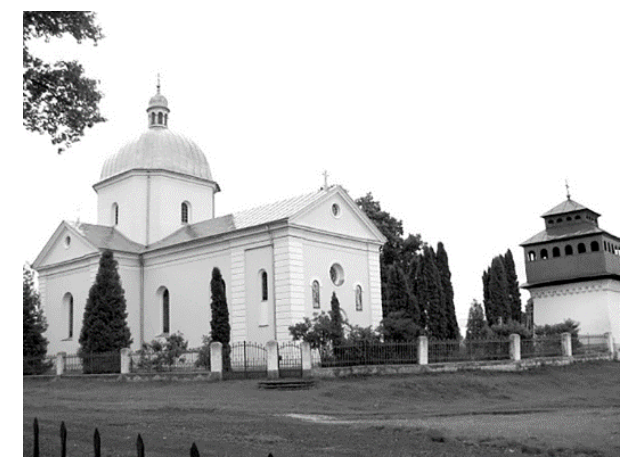

a

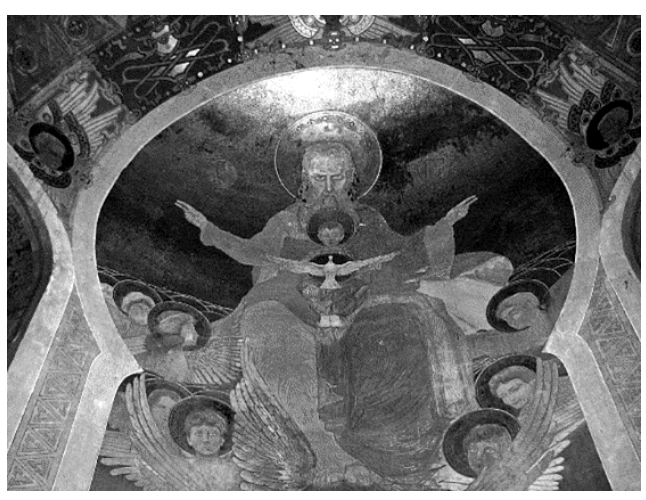

$\mathrm{b}$

Fig. 1. Arch. Michael Church, Pidberiztsi (a); Fragment of mural by M. Sosenko (1907) on the apse top (b); photo by A. Tyrpych, 1996
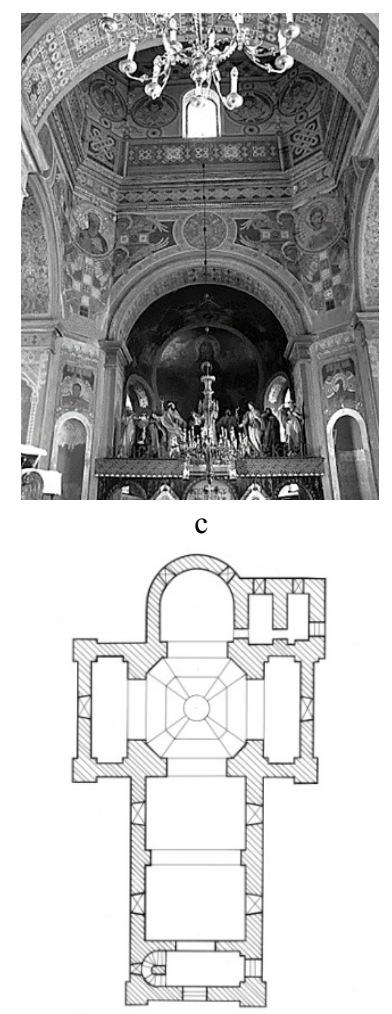

c1

Fig. 2. Polychrome painting, central dome of transept (c);

Layout of Arch. Michael

Church, Pidberiztsi performed

by A. Tyrpych (c1), 2015

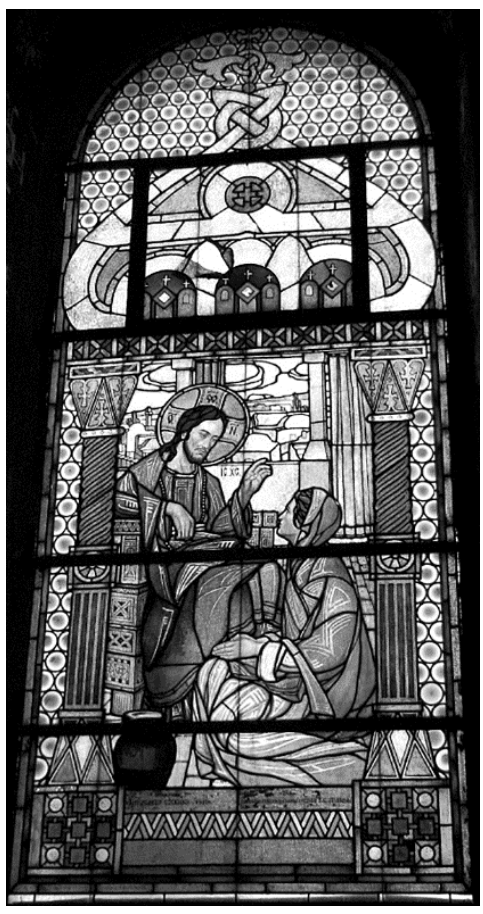

Fig. 3. Arch. Michael Church, Pidberiztsi;

stained-glass window, northern wall of apse; photo by A. Tyrpych, 2005

St. Nicholas Church in Zolochiv, Lviv region, is the architectural monument of the XVIth century, which back in the past used to be a part of the defensive constructions of Zolochiv in Hlynianske suburb. The defensive features of St. Nicholas Church are preserved nowadays and include thickness of walls, window apertures, fittings, etc. The construction started in the XVIth century and finished in the early XVIIth century; its founder is Mykola Vasyl Pototskyi; the church was restored in 1765; the sculptor of the stone plastic arts on the church facade is Frantsisk Olenskyi; the author of polychrome paintings of 1911-1913 is Modest Sosenko (Hupalo, 2007, p. 12-15). The inscription states that back in 1911-1913 the interior space of the church, namely murals, was fully reconstructed and restored. The task was assigned to Modest Sosenko, who created the new conception of decorating spatial composition of church interior with the help of polychrome paintings and followed the traditional for him idea of combining Neo- 
Byzantine stylistics and modernist aesthetics. In 1940s, during the Soviet period, St. Nicholas Church housed the museum of atheism. The iconostasis was dismantled; the icons and the elements of carvings and plastic arts were sent to Lviv National Museum named after A. Sheptytskyi, Museum of History of Religion and Lviv Art Gallery. In 1990, when Greek Catholic church was legalized, the building was transferred to serve the liturgical needs of Zolochiv Basilian Monastery. In 1991, scientific expedition (V. Radomska) was organized and its objective was to examine the monuments of architecture with murals and iconostases by Modest Sosenko. It helped to record the real state of polychrome painting preservation as of the moment of changing the functional purpose of the interior space (Fig. 5). In general, the expedition noted the satisfactory and integral state of mural preservation, which could enable the possibility of carrying out the professional conservation and restoration works. Murals in the sanctuary part of the church are preserved most fully, because it used to be the staff area for the museum workers. Repeated changes and renewals are spotted at the narthex top and walls. The reasons for this are the waterproof defects in the roof cladding and the mental habit of "renewing" the entrance transit zones in public buildings. The original name inscriptions on the northern and southern supporting walls of the nave and the narthex were partially covered because the content and the mentioned personalities were "hostile" to the Soviet ideology. As of the spring of 1991, the conclusions of the scientific and restoration expert evaluation outlined the following problems: general powdering of the polychrome painting structure (loss of binding media) and weakening of its connection with the plaster base; cracking, detachment of layers and peeling of plaster; significant surface contamination of the structure of paint layers; salt efflorescence in the structure of plaster and painting; repainting of certain fragments of art work; partial peeling and mechanical damage of paint layers.

In 2013, the next expedition (restoration artist V. Radomska) was organized and it detected the following changes in the interior space of the architectural monument: - the reconstruction of iconostasis was carried out with the serious changes in stylistics and iconographic content; - the conducted restoration works caused the significant losses in the original coloristic patterns and the texture of polychrome paintings.

The capital repair of the building was conducted in 2000 by efforts of Father Hegumen Volodymyr Palchynskyi. Following the initiative of Father Vasyl Tuchapets, Hegumen of the Basilian monastery, the group of specialists from the Lviv branch office of National Scientific and Research Restoration Center in Ukraine restored the wall murals painted by Modest Sosenko (Utkovych, 2008, p. 130-135). Restoration was executed using the method of preserving the patterns and compositional structure of the original intention of Modest Sosenko. It included integral repainting of an area and partial replication in accordance with the author's painting and coloristic patterns. The technique of restoration toning in the areas of original painting loss was not detected (Fig. 6). Macro photofixation used in the process of examining the polychrome paintings has outlined the significant differences between the original and the "renewed" coloristic patterns. The subtle texture of glue paintings by Modest Sosenko was leveled down and became monolithic and dumb. The date of "restoration" is recorded at the memorial inscription, located at the supporting northern wall of the nave and the narthex. Later in 2001-2003, the iconostasis was restored by efforts of Father Hegumen Klymentii Stasiv. The external architectonics of the church has also changed. In the past, the lower part of the building socle and the buttress used to have the bare brick texture of the calcareous rock. However, as of 2014, the stone foundation was covered with plaster, most probably without the preliminary correction of the horizontal waterproof system. It affected plaster and caused the increase of humidity in the lower part of foundation and walls. Macro photofixation revealed the tendency of the selective monument preservation, as the earliest architectural details and limestone sculptures made by F. Olenskyi are undergoing the process of gradual deterioration. In general, the object is hypothetically preserved, even though the authenticity of the elegant coloristic patterns and the specific texture that belong to the characteristic technical and technological features of polychrome paintings by Modest Sosenko are irreversibly lost. 


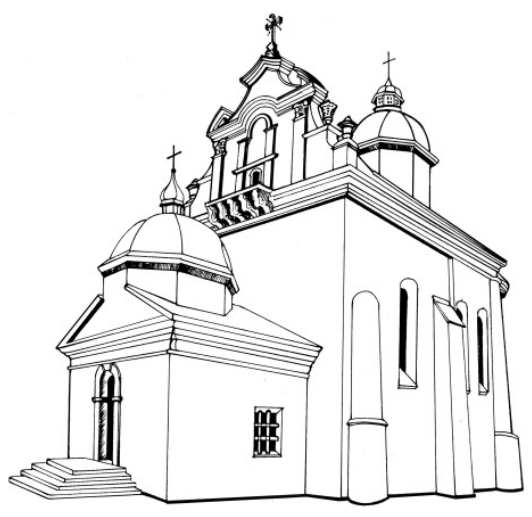

Fig. 4. St. Nicholas Church, Zolochiv, graphics by A. Tyrpych, 2015

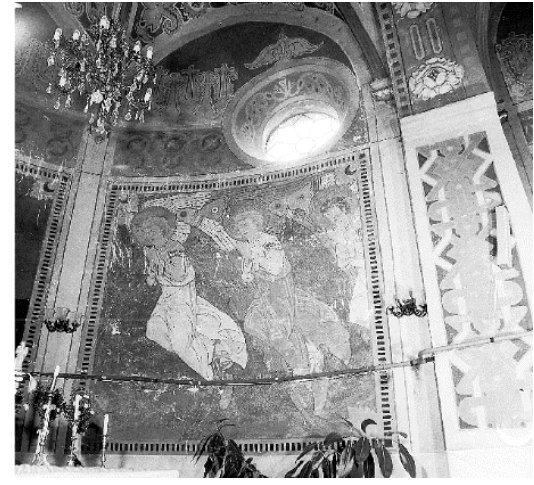

Fig. 5. Polychrome paintings by M. Sosenko (1911-1913), photo by V. Radomska, 1991

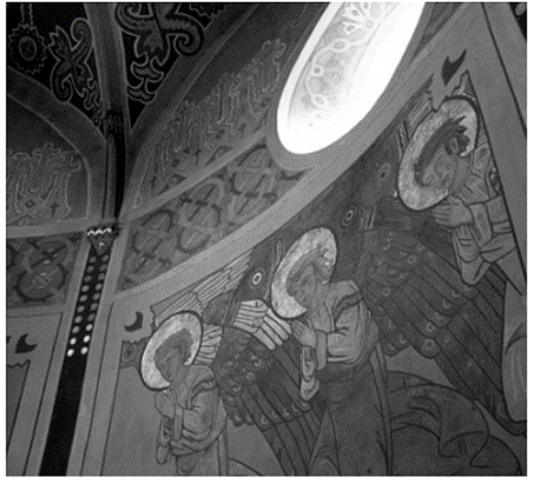

Fig. 6. Polychrome paintings by M. Sosenko (1911-1913), photo by A. Tyrpych, 2013

Church of Resurrection of Christ, located in Polyany village (Rykiv village till 1946), Zolochiv district, Lviv region, was designed by the architect V. Nahirnyi and dates back to 1903. In 1913-1914, Modest Sosenko created icons for the iconostasis and the two side altars and painted the central dome of the nave (Fig. 7-9).

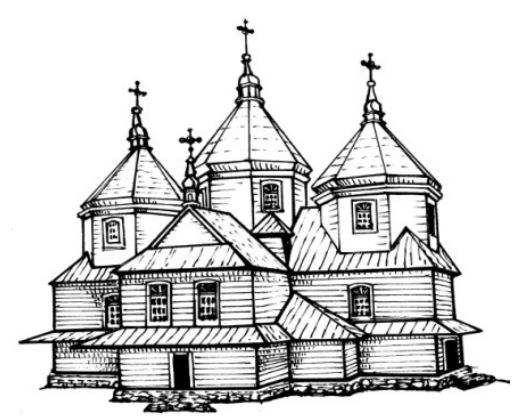

Fig. 7. Church of Resurrection of Christ, Polyany, graphics by A.Tyrpych, 2015

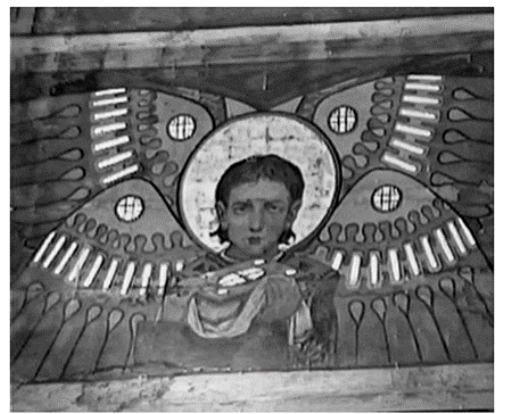

Fig. 8. Polychrome paintings by M. Sosenko (1913-1914), photo by A. Tyrpych, 1991

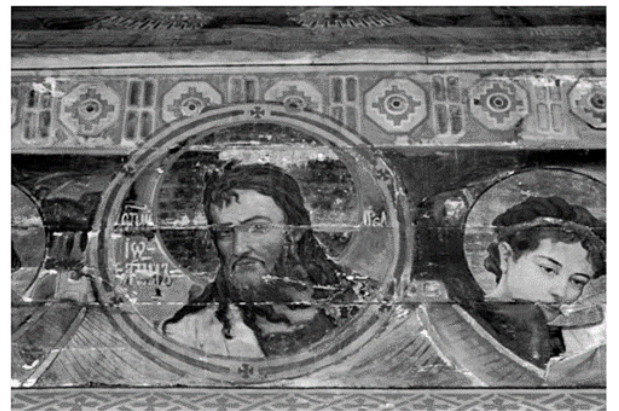

Fig. 9. Polychrome paintings by M. Sosenko (1913-1914), photo by A. Tyrpych, 2015

During the expeditions aimed to evaluate the preservation state of the monument of architecture (V. Radomska, 1991, 1996, 2016), we have noticed the gradual self-deterioration of Modest Sosenko polychrome paintings, located at the junctions of wooden constructions under the central dome space (Fig. 9). Partial detachment of linen canvas at the junctions of wooden boards resulted in the peeling of levkas and paint layers of the polychrome paintings. The situation was worsened by the unsatisfactory waterproof characteristics of the church roof cladding. The unstable temperature and humidity regime triggered the deterioration of joints between wooden boards and the appearance of fungi spores, etc. (Fig. 9). It should be pointed out that in 2018 the region council allocated funds to cover the central dome of the church, which could significantly influence the preservation of polychrome (elected official M. Babinska). Currently, those unique murals that are still preserved in their authentic form require urgent attention of experienced and professional restoration artists who specialize in the area of preserving decorative and monumental art objects, located in the structure of an architectural building. The program of restoration works should be based on the idea of preserving original texture, coloristic patterns, and technical and technological peculiarities. It should prevent the unprofessional approach and the "renewal" experience observed in St. Nicholas Church in Zolochiv. The 
preservation state of the icons in iconostases and two side altars, created by Modest Sosenko, is satisfactory and no renewals were made.

\section{Conclusions}

The study of the material structure of an object from the stratigraphic aspect gives the possibility of conducting professional restoration and eliminating the consequences of aesthetic renewals that deteriorate the authenticity and hinder the subsequent preservation of an object. Contrary to renewals, professional restoration aims at discarding the influence of new layers that were made with time and uncovering the authenticity of an artwork in the eyes of the contemporary society. Such works become topical while remaining a part of the past that is embodied in the consciousness of the contemporaries. However, the preference for the aesthetic and stylistic factor results in some differences in terms of the principles of preservation, conservation, and restoration of this authenticity. The restoration theory failed to elaborate the uniform principles of preserving a work of art which would not be a matter of controversy and "supremacy of taste". These assumptions about the preservation state and the principles of restoration of polychrome paintings by Modest Sosenko are based on the examples of three churches in Lviv region. In one of them (St. Nicholas Church in Zolochiv), the complex original authenticity is lost, while in two others (Arch. Michael Church in Pidberiztsi and Church of Resurrection of Christ in Poliany), the authenticity is being self-deteriorated due to the lack of funds. The absolutely vandal approach to "restoration" can be observed as based on the example of Dormition of Mother of God Church in Slavsk, Lviv region, which was decorated with the polychrome paintings by M. Sosenko (though significantly renewed and reconstructed). For the period of a week the local community destroyed the historic layers of plaster with polychrome paintings without any approval (June, 2019).

The combination of scientific and practical studies of art experts, restoration artists, chemists and technologists can prevent the subsequent unprofessional interventions which are accompanied by the change of aesthetics and material structure of a work and the disregard for its historical and artistic value. The comprehensive research of one object can serve as the basis for preserving and protecting sacred cultural heritage of the first half of the XXth century, which is presupposed by the Ukrainian legislation.

\section{References}

[1] Biuletyn Informacyjny Konserwatorów Dzieł Sztuki. 2017. Łódź: Fizet - Druk.

[2] Brandi, C., Teoria restauracji. 2006. Warszawa: Oficyna Drukarska - Jacek Chmielewski.

[3] Kutnyj, A., Sakrale Holzarchitektur in den Karpaten.Bauforschung an ausgewählten Beispielen in der West-Ukraine. 2009. München: Kessler Druck.

[4] Откович, Т. М., 2008. Реставрація настінних розписів Модеста Сосенка в церкві Св. Миколая в Золочеві. Бюлетень ННДРЦ Украйни (Львівський філіал), 2008,10, с. 130-134.

[5] Радомська, В. Р., 2006. Модест Сосенко - автор розпису храму Архистратига Михаїла у Підберізцях. Збереження та порятунок сакральних пам'яток Галичини, 2006, 1, с. 50-54.

[6] Biuletyn Informacyjny Konserwatorów Dzieł Sztuki. 2017. Łódź: Fizet - Druk.

[7] Brandi, C., Teoria restauracji. 2006. Warszawa: Oficyna Drukarska - Jacek Chmielewski.

[8] Kutnyj, A., Sakrale Holzarchitektur in den Karpaten.Bauforschung an ausgewählten Beispielen in der West-Ukraine. 2009. München: Kessler Druck.

[9] Otkovych, T. M., 2008. Restoration of murals by Modest Sosenko in St. Nicholas Church in Zolochiv. Biuleten NNDRTs Ukraiiny (Lvivskyi filial), 2008, 10, pp. 130-134.

[10] Radomska, V. R., 2006. Modest Sosenko as an author of paintings in Arch Michael Church in Pidberiztsi. Zberezhennia ta poriatunok sakralnykh pamyatok Halychyny, 2006, 1, pp. 50-54. 
Богдан Черкес, Віолетта Радомська

\section{СУЧАСНИЙ СТАН ЗБЕРЕЖЕНОСТІ ТА ПРОБЛЕМАТИКА РЕСТАВРАЦІЇ ПОЛІХРОМІЙ МОДЕСТА СОСЕНКА В СТРУКТУРІ САКРАЛЬНОЇ АРХІТЕКТУРИ}

Анотація. Сучасна тенденція збереження пам'яток нерухомої спадщини набрала вкрай негативного характеру, оскільки надалі залишається неврегульованою законодавча пам'ятко-охоронна діяльність держави та релігійних громад, які стають «власниками» визначних сакральних споруд. Для комплексного збереження архітектурного об'єкта вкрай важливо синхронізувати багатовекторні дослідження фахівців усіх напрямів. Яскравим прикладом може слугувати стан збереженості стінописів відомого модерніста першої чверті ХХ століття Модеста Сосенка (1875-1920), виконаних у структурі інтер'єрного середовища украйнських иерков. Руйнівні процеси, ідеологічні прерогативи, зміна естетичних принципів призвели до тотального знищення цих унікальних пам'яток декоративно-монументального мистецтва. На основі емпіричних, науково-реставрачійних досліджень розглянуто збереженість та проблематика реставрації сакральних поліхромій Модеста Сосенка на теренах Львівської області. Серед значної спадщини иерковних стінописів та іконостасів, а це понад 12 об'єктів, станом на сьогодні збереглось: три іконостаси, церковні поліхромії в трьох храмах. Визначити стан збереженості авторських поліхромій та розробити рекомендаиії щодо охорони $і$ реставрачії декоративно-монументальних творів в архітектурі вкрай важливо, оскільки маємо нещодавній негативний пам'яткоохоронний досвід повного знищення історико-мистеиької спадщини - стінописів Модеста Сосенка та Юліана Буиманюка в иееркві Успіння Богородиці, смт. Славське Львівської обл. (червень 2019 р.). На основі узагальнення досвіду украӥнських та іноземних науковців і реставраторів розроблено рекомендації щодо охорони та реставрації ще існуючих автентичних стінописів і вітражів авторства Модеста Сосенка (1907-1910 рр.) в інтер'єрі церкви Архистратига Михаїла с. Підберізиі Львівської області. Такий об'єкт доцільно включити в перелік культурної спадщини для занесення до Державного реєстру нерухомих пам'яток Украӥни, як об'єкт монументального мистеитва. Сучасна науково-реставраційна галузь зобов'язана розробити дієву концепцію популяризаџії, просвітництва та тісної співпраці з активом громад для збереження пам'яток нерухомої спадщини, які переходять у їхню власність. Результати дослідження сприяють виріменню проблем охорони, реставрації, збереження та використання архітектурної спадщини України, щя відповідає потребам загальнодержавних та міських програм розвитку.

Ключові слова: поліхромія, сакральна архітектура, Модест Сосенко, збереженість, реставрація, фізико-хімічні дослідження, реставрачійний зондаж. 